ISSN: 2277-3754

ISO 9001:2008 Certified

International Journal of Engineering and Innovative Technology (IJEIT)

Volume 10, Issue 1, July 2020

\title{
Finite element analysis of a compound die to make hexagonal washer
}

\author{
Dr B V S Rao, N Jyothirmayi \\ Asst Professor, Asst professor CBIT, Hyderabad
}

\begin{abstract}
Finite Element Analysis (FEA) has currently been developed into an efficient, user friendly tool for investigation of many metal forming processes. Thus by FEA, it is now possible to visualize any metal forming process to study strain, stress and other important forming conditions inside the work piece. FEA has also become an important industrial tool in connection with design and development of new forming processes and tools. This paper presents Stress and Elastic Strain analysis of a compound die which combines blanking and piercing operations. In the present work, FEA has been done for a compound die which is designed to make a hexagonal washer of M15 bolt using ANSYS software. This analysis is helpful for validating the design and developing the die.
\end{abstract}

Keywords: Finite Element Analysis, Metal forming, Stress analysis, Compound die, Blanking, Piercing, ANSYS.

\section{INTRODUCTION}

A large variety of sheet-metal forming processes are used in making aircraft, automobiles, kitchen utensils, furniture and other products. Sheet metal forming processes can be divided into two groups: cutting processes (shearing, blanking, punching, notching and so on) and plastic deformation processes (bending, stretch forming, drawing etc).

The first group of processes involves cutting material by subjecting it to shear stresses usually between punch and die. The punch and die may be any of any shape and the cutting contour may be open or closed. The second group of processes involves partial or complete plastic deformation of the sheet material.

Blanking is a cutting process in which a piece of sheet metal is removed from a larger piece of stock by applying required shearing force. In this process, the piece removed, called the blank, is not scrap but rather the desired part. Blanking can be used to cutout parts in almost any $2 \mathrm{D}$ shape, but is most commonly used to cut work pieces with simple geometries that will be further shaped in subsequent processes. Punching is a process in which the punch removes a portion of material from the larger piece or a strip of sheet metal. If the small removed piece is discarded, the operation is called punching; Figure1 shows difference between blanking and piercing, Die is the main tool used for these press working operations. It is a specialized tool used to cut or shape materials into pre-determined shapes. There are different types of dies- simple die, progressive die, compound die and combination die. Simple die performs only one operation like blanking or punching or drawing etc.

Manuscript received: 23 June 2020

Manuscript received in revised form: 19 July 2020

Manuscript accepted: 05 August 2020

Manuscript Available online: 15 August 2020
The die which performs two or more operations simultaneously at different work stations in a single stroke is known as a progressive die. Compound die performs two or more cutting operations, typically piercing and blanking at single station in single press cycle. The advantage of a compound die is the high and unsurpassed mechanical accuracy of a single step process. Die design is an important part of press metal working. Many parameters have to be considered while designing the dies for various sheet metal working operations. The construction of compound die is more complicated than progressive die. A common characteristic of compound-die design is the inverted construction, with the blanking die on the upper die shoe and the blanking punch on the lower die shoe. Figure 2 shows the compound die assembly and its various parts.
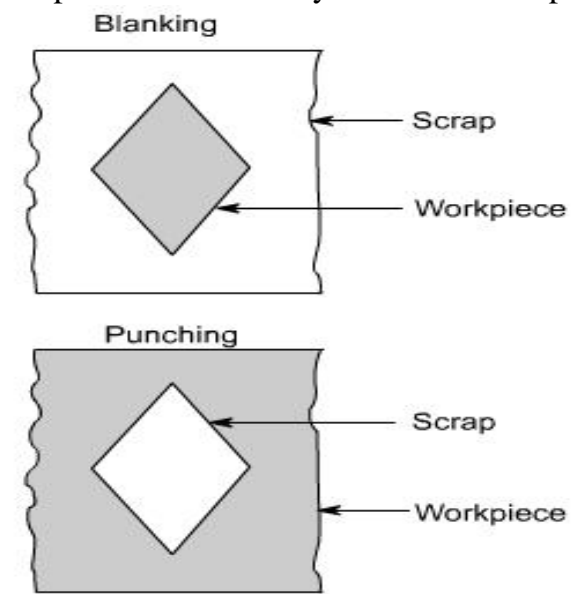

Fig 1: Blanking Vs Piercing operations

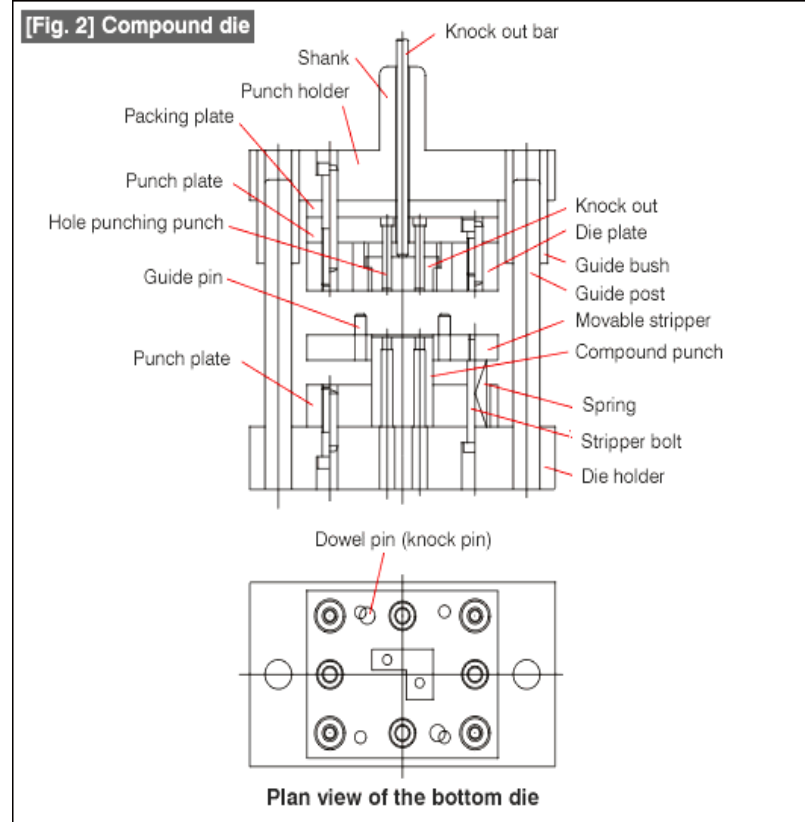

Fig 2: Compound Die assembly 
ISSN: 2277-3754

\section{ISO 9001:2008 Certified}

\section{International Journal of Engineering and Innovative Technology (IJEIT)}

\section{Volume 10, Issue 1, July 2020}

In this paper, Finite Element Analysis (FEA) is done for a compound die combining blanking and punching operations to validate its design. The die is designed to make a hexagonal washer of M15 bolt. 3D Modeling is done using SOLIDWORKS software and analysis is done using ANSYS software.

\section{METHODOLOGY}

Figure 3 shows a simple component called hexagonal washer for which a simple compound die needs to be designed.

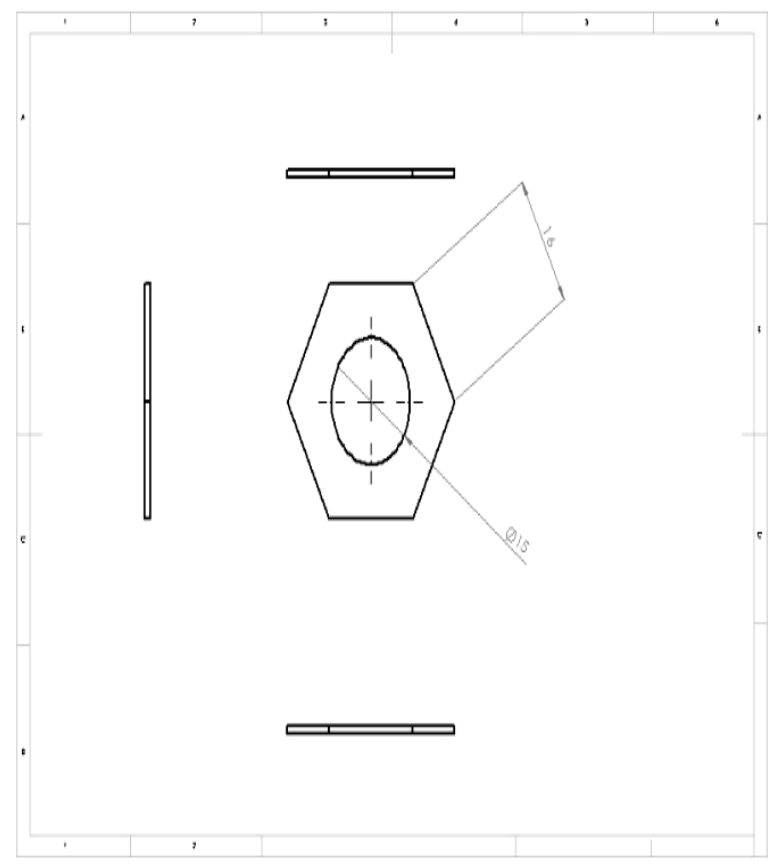

Fig 3: Hexagonal Washer to be made.

The specifications of washer to be made are given in the table 1 .

Table 1: Specifications of washer

\begin{tabular}{|c|c|c|}
\hline SNO & Description & specification \\
\hline 1 & Component name & hexagonal washer \\
\hline 2 & Type of tool & compound tool \\
\hline 3 & Sheet metal material & mild steel \\
\hline 4 & Sheet thickness & $1 \mathrm{~mm}$ \\
\hline 5 & Press tonnage & 8 tons \\
\hline
\end{tabular}

\section{A. Design of compound die}

As far as sheet metal working is concerned, the die design is very important aspect. Many parameters have to be considered while designing the dies for various sheet metal working operations.

\section{Selection of materials}

Press tools are generally made using $\mathrm{HCHCr}$, Steel alloys with high carbon. But before that based on many factors like cost, strength, hardness, strain and many parameters selection should be made. The materials used are D2, EN31. Mild Steel is used as supporting plate. Apart from that, materials like D3, high carbide materials, chromium steels and high speed steels are also used.

\section{Design and optimization of Punch and Die}

Some thumb rules and standards are used for die and punch size calculation. Force required for blanking and punching is also calculated. Optimization is carried out by selecting different materials for die and punch. By selecting different material for die and punch we get variety of choices for choosing particular material. On the basis of properties of different material we will optimize specific material for die and punch.

\section{Calculation of press capacity}

We have press capacity $=$ Fmax $* \mathrm{C}$

$$
\begin{aligned}
& \text { Where } \mathrm{C}=1.1 \text { to } 1.5 \text { for normal profile } \\
& \mathrm{C}=1.25 \text { to } 1.75 \text { for } \frac{\mathrm{d}}{\mathrm{t}}<2
\end{aligned}
$$

Press capacity $=$ Fmax $* \mathrm{C}$

$$
\begin{aligned}
& =8 \text { tons } * 9.81 * 1.5 \\
& =8 * 1000 * 9.81 * 1.5 \\
& =11720 \mathrm{~N}
\end{aligned}
$$

Energy of press $=$ Fmax $* C^{*}$ punch travel

$$
\begin{aligned}
& =8000 * 9.81 * 1.5 * 8 \\
& =94176 \quad \mathrm{~N}-\mathrm{m}
\end{aligned}
$$

\section{Minimum diameter of piercing}

We have piercing pressure $=(T) * \pi * \mathbf{d l}$ strength of the punch $=\sigma * \pi \frac{d^{-}}{4}$

If we equate the piercing and strength of the punch we obtain the minimum diameter of piercing

$$
\begin{aligned}
& \operatorname{ie}(T) * \pi * \mathrm{dl}=\sigma * \pi \frac{d^{*} 2}{4} \\
& \mathrm{~d}=\frac{(T)}{\sigma} 4 * \mathrm{t} \\
& \mathrm{d}=2 \mathrm{t} \quad(\sigma=2 \tau)
\end{aligned}
$$

as our compound die piercing punch diameter is 15 so it si safe ie $15 \mathrm{~mm}>2 \mathrm{t}$

$15 \mathrm{~mm}>2 \mathrm{~mm}$

Minimum size of punched holes depending upon their shapes are as follows:
0.7 to $1.2 \mathrm{t}$ for soft steel
0.9 to $1.5 \mathrm{t}$ for steel
1.75 to $2 \mathrm{t}$ for $\mathrm{Ti}$ alloys
0.6 to $0.9 \mathrm{t}$ for brass and copper
0.5 to $0.8 \mathrm{t}$ for zinc
0.4 to $0.7 \mathrm{t}$ for Bakelite
0.3 to $0.6 \mathrm{t}$ for cardboard and paper

\section{Die block thickness}

Die block thickness can be calculated as follows

Die block thickness $=\mathrm{T}=\sqrt[3]{F}$ where $\mathrm{F}$ is in tons

$$
=\sqrt[3]{8}=2 \mathrm{~mm}
$$

Die block thickness is taken as $20 \mathrm{~mm}$

\section{Relief angle}

As already mentioned relief angle should be

${ }^{1}{ }^{0}$ to $1^{0}$ for small die

$$
\begin{aligned}
& 1^{0} \text { to } 2^{0} \text { for average die } \\
& 2^{0} \text { to } 3^{0} \text { for large die }
\end{aligned}
$$

As our compound die is average die relief angle should be between $1^{0}$ to $2^{0}$

So relief angle for die is equal to $\tan ^{-1} \frac{1}{40}$ 
ISSN: 2277-3754

ISO 9001:2008 Certified

International Journal of Engineering and Innovative Technology (IJEIT)

Volume 10, Issue 1, July 2020

Area of die opening border

Table 2: Area of die opening border

\begin{tabular}{|l|l|}
\hline Maximum cutting force $(\mathrm{KN})$ & $\begin{array}{l}\text { Area between die opening } \\
\text { border }\left(\mathrm{cm}^{2}\right)\end{array}$ \\
\hline 200 & 3.25 \\
\hline 500 & 6.5 \\
\hline 750 & 9.75 \\
\hline 1000 & 13.00 \\
\hline
\end{tabular}

Area of die opening border for various cutting forces are shown in the table 2.

\section{Fastening of die block}

Screw diameter $=0.5 \mathrm{t}$ for $\mathrm{T}<19 \mathrm{~mm}$ $=0.4 \mathrm{t}$ for $\mathrm{T}>19 \mathrm{~mm}$

We took it as $8 \mathrm{~mm}$ which is greater than $0.4 \mathrm{t}$ for the sake of safety and alignment purpose

Punch length

Maximum length of punch is equal to

$$
\begin{aligned}
\mathrm{L} & =\frac{\pi d}{\mathrm{~g}} \operatorname{sqrt}\left(\frac{\mathrm{Ed}}{\pi \mathrm{t}}\right) \\
& =\frac{\pi \cdot 15}{\mathrm{~g}} \operatorname{sqrt}\left(\frac{2 * 100000 * 15}{400}\right) \\
& =510 \mathrm{~mm}
\end{aligned}
$$

But generally punch length is taken as 60 to $85 \mathrm{~mm}$.So 64 $\mathrm{mm}$ is taken as length of the punch.

\section{Design of spring}

Maximum force on spring is should be as follows

Fmax $>1.5 * \frac{\text { Fstr }}{i} \quad(i=1)$

Where Fstr=stripper force

$$
\begin{aligned}
& =0.05 \text { to } 0.08 * \mathrm{~F} \\
& =0.07 * 8000 \\
& =5493.6 \mathrm{~N}
\end{aligned}
$$

$\mathrm{Fmax}=1.5 * \frac{549 \mathrm{a} .6}{1}=8240.4$

Fmax $=8240.6 \mathrm{~N}$.

\section{Calculation of punching force and blanking force}

\section{Punching}

Punch size $=15 \mathrm{~mm}+$ allowances

$$
\begin{aligned}
& =15+0.05 \\
& =\mathbf{1 5 . 0 5} \mathrm{mm}
\end{aligned}
$$

Die size $=$ punch size $+2 \mathrm{c}$

$$
\begin{gathered}
\text { Where } \mathrm{c} \text { is clearance } \\
=15.05+2 \\
=\mathbf{1 5 . 2 5} \mathbf{m m}
\end{gathered}
$$

Punching force $=\pi \mathrm{dt} \tau$

Where $\mathrm{d}$ is diameter of punch

$\mathrm{t}$ is thickness of metal sheet

$\tau$ is shear force

Punching force $=\pi * 15.05 * 1 * 400$

$$
=18912.38 \mathrm{~N}
$$

\section{Blanking}

Blanking force $=$ perimeter $*$ thickness $*$ shear force

$=$ (perimeter of hexagonal-perimeter of

circle)*thickness* shear force

$=(6 *$ side of hexagon $-\pi \mathrm{d}) * 1 * 400$

$=(6 * 16-\pi * 15) * 400$

$$
\begin{aligned}
& =48.876 * 400 \\
& =19550.44 \mathrm{~N}
\end{aligned}
$$

\section{B. $2 D$ modeling of the compound die}

The 2D modeling of the die is made using SOLIDWORKS
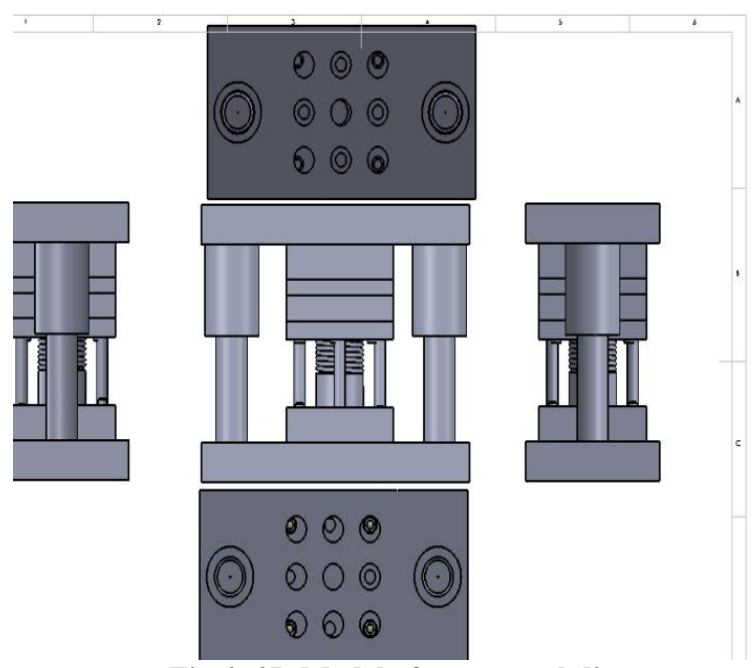

Fig 4: 2D Model of compound die

The five views of compound die in the first angle projection are shown in figure 4.

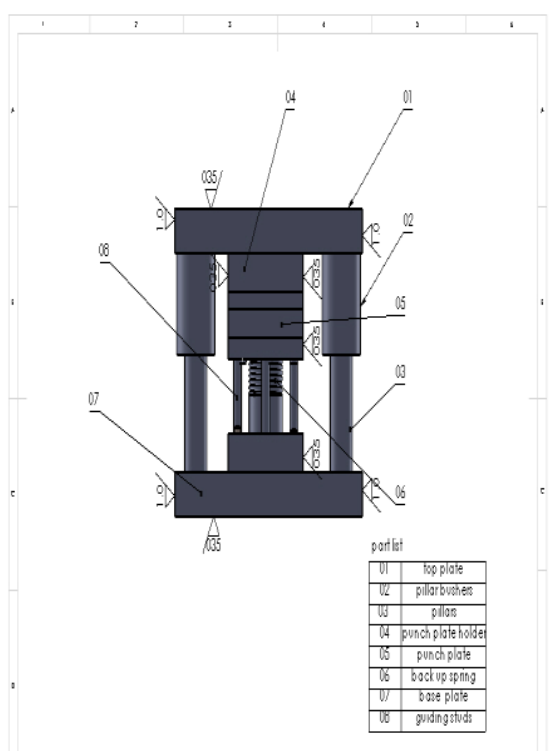

Fig 5: Surface roughness values and parts list Parts list and surface roughness values are shown in the figure 5.

\section{Finite Element Analysis of Compound Die}

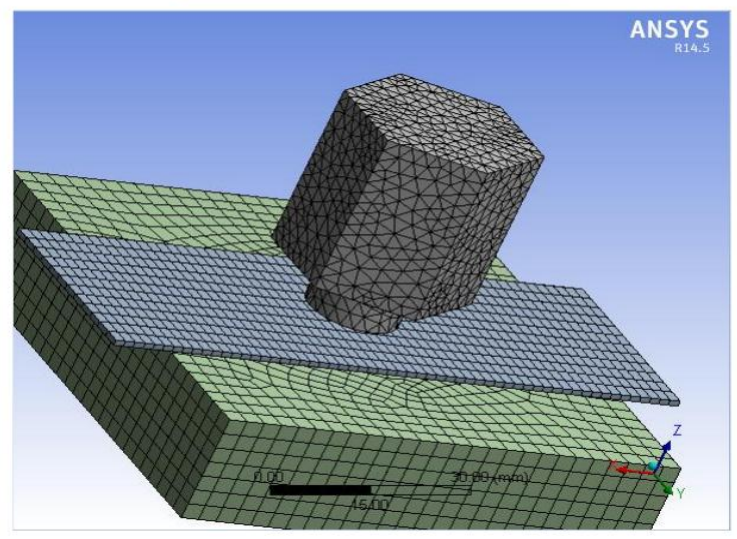

Fig 6: FEA model of Die Set 
ISSN: 2277-3754

\section{ISO 9001:2008 Certified}

International Journal of Engineering and Innovative Technology (IJEIT)

Volume 10, Issue 1, July 2020

To carry out the analysis, 3D-Solid model of the all functional elements are modeled in SOLIDWORKS software.

For this by using ANSYS software the input parameters are given i.e. material properties, boundary condition, load applied and model of component to get desired output i.e. deflection \& stress on component.

\section{RESULTS}

The resulting stress values are shown in the below table 3 and strain values are shown in table 4 .

Table 3: stress values

Model (A4) > Explicit Dynamics (A5) > Solution (A6) > Equivalent Stress

\begin{tabular}{|c|c|c|}
\hline Time [s] & Minimum [MPa & Maximum [MPa] \\
\hline $1.1755 \mathrm{e}-038$ & \multirow{21}{*}{0.} & 0. \\
\hline $2.5002 \mathrm{e}-004$ & & 348.3 \\
\hline 5.e-004 & & 681.87 \\
\hline $7.5001 \mathrm{e}-004$ & & 206.82 \\
\hline 1.e-003 & & 655.87 \\
\hline $1.25 \mathrm{e}-003$ & & 868.81 \\
\hline $1.5 \mathrm{e}-003$ & & 871.28 \\
\hline $1.75 \mathrm{e}-003$ & & 862.47 \\
\hline 2.e-003 & & 854.15 \\
\hline $2.25 \mathrm{e}-003$ & & 847.2 \\
\hline $2.5 \mathrm{e}-003$ & & 841.27 \\
\hline $2.75 e-003$ & & 836.04 \\
\hline 3.e-003 & & 831.34 \\
\hline $3.25 \mathrm{e}-003$ & & 827.02 \\
\hline $3.5 \mathrm{e}-003$ & & 823.04 \\
\hline $3.75 \mathrm{e}-003$ & & 819.33 \\
\hline $4 . e-003$ & & 815.88 \\
\hline $4.25 \mathrm{e}-003$ & & 812.62 \\
\hline $4.5 e-003$ & & 809.52 \\
\hline $4.75 e-003$ & & 806.57 \\
\hline $5 . e-003$ & & 803.77 \\
\hline
\end{tabular}

The following figure 7 shows Stress Vs Time graph

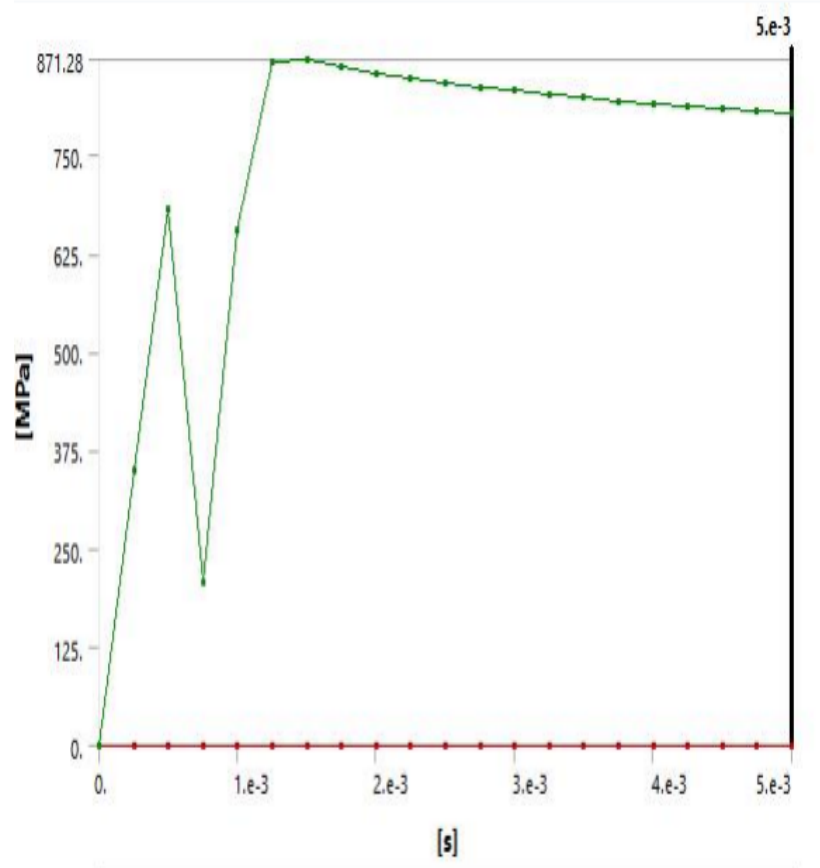

Fig 7: Stress Vs Time Graph
Table 4: Strain values

Model (A4) > Explicit Dynamics (A5) > Solution (A6) > Equivalent Elastic Strain

\begin{tabular}{|c|c|c|}
\hline Time [s] & Minimum $/ \mathrm{mm} / \mathrm{mm}$ & Maximum $[\mathrm{mm} / \mathrm{mm}$ \\
\hline $1.1755 \mathrm{e}-038$ & \multirow{18}{*}{0.} & 0. \\
\hline $2.5002 \mathrm{e}-004$ & & 0.40851 \\
\hline $5 . e-004$ & & 0.63063 \\
\hline 7.5001e-004 & & 0.76789 \\
\hline 1.e- -003 & & 0.97197 \\
\hline $1.25 \mathrm{e}-003$ & & 1.0415 \\
\hline $1.5 \mathrm{e}-003$ & & 1.0532 \\
\hline $1.75 \mathrm{e}-003$ & & 1.0517 \\
\hline 2.e-003 & & 1.0485 \\
\hline $2.25 \mathrm{e}-003$ & & 1.0457 \\
\hline $2.5 \mathrm{e}-003$ & & 1.0439 \\
\hline $2.75 \mathrm{e}-003$ & & 1.0426 \\
\hline 3.e-003 & & 1.0418 \\
\hline $3.25 e-003$ & & 1.0413 \\
\hline $3.5 e-003$ & & 1.041 \\
\hline $3.75 e-003$ & & \multirow{2}{*}{1.0408} \\
\hline 4.e-003 & & \\
\hline $4.25 \mathrm{e}-003$ & & \\
\hline
\end{tabular}

The following figure 8 shows StrainVs Time graph

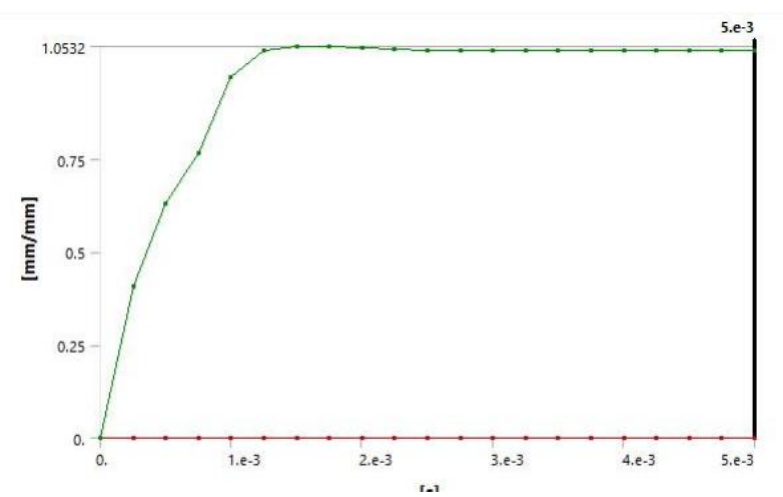

Fig 8: Strain Vs Time Graph

All the stress and strain values are found to be within the required limits. A compound die set shown in figure 9 is developed as per the design validated by analysis.

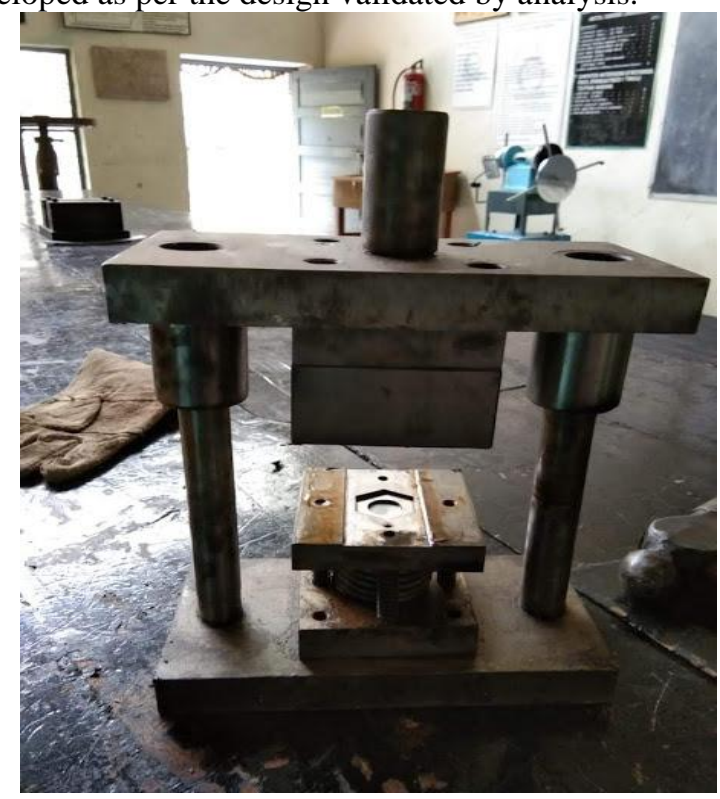

Fig 9: Fabricated Compound Die set 


\section{ISSN: 2277-3754 \\ ISO 9001:2008 Certified \\ International Journal of Engineering and Innovative Technology (IJEIT)}

Volume 10, Issue 1, July 2020

The die is tested on a fly press of suitable capacity shown in figure 10 to produce a hexagonal washer of M15 bolt shown in figure 11 . The hexagonal washer made by the die is to the desired specifications.

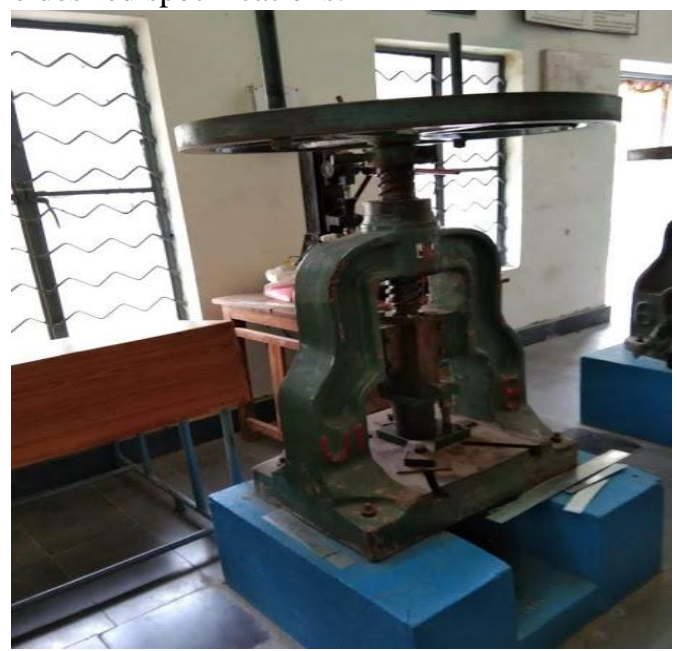

Fig 10: Fly press used for testing the compound die

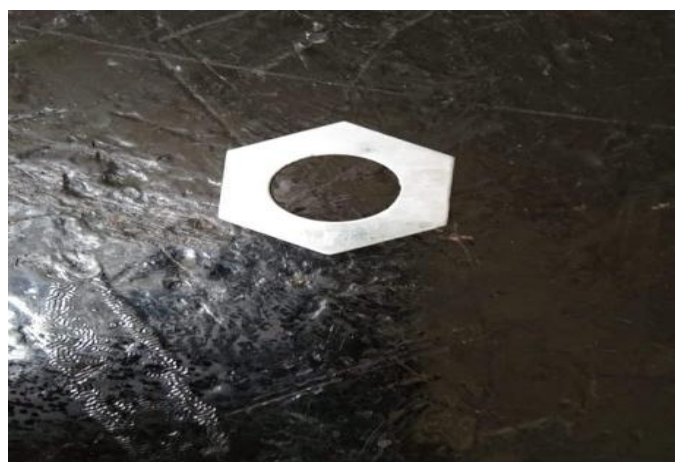

Fig 11: Hexagonal washer made using the developed compound die

\section{CONCLUSION}

Compound die for the required hexagonal washer is designed and analysis is carried out using ANSYS software. The resulting stresses and strains are found to be within the required limits.

This analysis is helpful for validating our die set design and developing the compound die. The.fabricated die is tested successfully on a fly press of suitable capacity. The hexagonal washer of M15 bolt made on the die is to the accurate dimensions. This die set is being used successfully in the Metal forming Lab of Chaitanya Bharathi Institute of Technology, Hyderabad.

\section{REFERENCES}

[1] David A. Smith, die design handbook, 3rd edition, chapter 27, PRESS DATA.

[2] V. S. BhajantrI, G. B. Kapashi , S. C. Bajantri, "Analysis of Progressive Dies", International Journal of Engineering and Innovative Technology (IJEIT) Volume 3, Issue 7, January 2014.

[3] J.N Reddy "An introduction of finite element method" Tata McGraw Hills, 2ndedition.

[4] Dr. M.Venkateswara Rao, "Design and Analysis of Progressive Toole. International Journal of Engineering
Research \& Technology (IJERT) Vol. 1 Issue 6, August 2012.

[5] Vishwanath M.C., "Design of Progressive Draw Tool"e. International Journal of Scientific and Research Publications, Volume 3, Issue 8, August 2013, ISSN 2250-3153.

[6] Rupali Chavan, Navneet Patil, "Design, Development and Analysis of Press Tool for an Industrial Parte, International Journal of Mechanical and Industrial Technology, 2016, pp.49.

[7] B. F. Satpute, M. S. Harne, "Design and Development of Compound Die for Bearing Cap" International Journal of Recent Engineering Research and Development (IJRERD) Volume No. 02 - Issue No. 01, ISSN: 2455-8761 June- 2016, pp. 50-61.

[8] N.Jyothirmayi, Dr. B.V.S.Rao, "The Design and Fabrication of A Compound Die To Make Hexagonal Washer", International Journal of Mechanical and Production Engineering Research and Development (IJMPERD), Vol. 9, Issue 4, Aug 2019, 517-528. 